\title{
非ダルシ一型抵抗則を用いた捨石水制内部流れ および3次元LESによる水制周辺流れの数値計算 NUMERICAL CALCULATION OF FLOWS BY A RUBBLE MOUND GROIN BY A COMBINED MODEL OF A POROUS FLOW MODEL WITH A NON- DARCIAN RESISTANCE LAW AND A 3-DIMENSIONAL LES MODEL
}

\author{
赤堀良介 ${ }^{1} \cdot$ 道奥康治 ${ }^{2}$ \\ Ryosuke AKAHORI and Kohji MICHIOKU \\ 1正会員 Ph.D. 東京工業大学大学院助教 理工学研究科（广152-8552 東京都目黒区大岡山2-12-1） \\ 2フェロー会員 工博 神戸大学大学院教授 工学研究科（广657-8501 神戸市灘区六甲台町1-1）
}

This study present a combined numerical model of a porous flow model that employ a non-Darcian resistance law and a 3-dimensional Large Eddy Simulation model in order to investigate 3-dimensional and temporal structures of flows around a rubble mound groin. A model's accuracy is cross-checked by comparing numerical results to observed results of an existing experiment, and model's results show good agreement in terms of time- and depth-averaged sense. Calculation results also imply that a permeable groin restricts growth of secondary flows in a constriction section. However, a combined model is not able to produce unsteady characteristics of flows that are caused by small scale and structured turbulences in a down-stream region of a groin.

Key Words : open channel, porous media, non-Darcian, rubble mound groin, LES

\section{1. はじめに}

近年の自然環境への意識の高まりや平成9年に改正さ れた河川法などを背景として，これまでのように経済性 を優先したコンクリートや鋼製の不透過性の素材を用い た構造物によるものでなく, 自然石等を用いた透過性の 構造物による河川整備が全国でさかんに進められるよう になってきている. このような構造物のひとつとして自 然石を積み上げた堰（捨石堰）が挙げられ，わが国にお いても近代以前の時代から農業取水堰として利用されて きた歴史を持つ。これら捨石堰は，その素材の透過性や 形状的, 構造的な特性によって, 堰下流の水質の改善や 景観の点など環境面で利点を持つ一方，コンクリート製 などの堰と比較して脆弱であり, その整備に当たっては 適切な設計，施工，および維持管理が必要とされる．近 代以前においてこれらは経験的に対処されてきたが，現 代においては水理学的根拠に基づく判断が必要であり, 捨石堰の工学的特性の解析が, 今後の多自然工法の普及 のためにも必須であると考えられる.

捨石堰および捨石水制の水理特性の解明に当たって, これまで, 前野らは実験により捨石堰の破壊時の段階的
な特性を明らかにしたほが ${ }^{1)}$ VOF法を用いた鉛直2次元 断面での堰周辺部の流れの数值解析を行い, 水面形分布 などの良好な再現に成功している2)。 また，道奥らは水 理実験と理論解析から流量や捨石による多孔体内部の抵 抗則等，水理諸量の検討を行い3)，そこで得られた知見 から, 水深平均の2層モデルによる透過性構造物周辺の 開水路部と透過水制内部の流れを同時に計算可能な数值 計算モデルを提案し，捨石水制周辺の流れに関して，水 深平均, 時間平均された結果に関して良好な再現性を提 示することに成功している4).

数值計算による捨石堰および水制の解析は，水理実験 では得難い構造物内部の流れや周辺でのせん断応力の分 布といった情報を提供することが可能であり, 対象周辺 の河床変動や構造物自体に対する応力特性を詳細に検討 寸る際に有効であると考えられる. しかしながら，上記 に示した既往の研究では鉛直方向もしくは水深平均の 2 次元的かつ定常的な流れの把握に留まっており, 堰や水 制のもたらす3次元的, 非定常な流れの把握は研究対象 とはしていない. Akahori ${ }^{5}$ はLESによる3次元非定常数值 計算によって, 水制先端から下流に生じる鉛直方向のせ 儿断面のみでなく, 水制によって急縮される部分に生じ る流下方向に軸を持つ2次流の存在が，浮遊砂輸送に大 
きく関わる剥離渦の間欠的な生成に影響を与えることを 示唆した. 最終的に構造物周辺の土砂輸送等の合理的検 討を目標とするに当たっては，透過型構造物周辺での非 定常3次元解析が有効であると考えられる.

これまで, 不透過型の水理構造物周辺の流れに対して は3次元モデルの応用が進んでおり, 長田ら ${ }^{6}$ はRANS系 乱流モデルと移動境界座標を水制周辺の流れに適用し， 非定常流れと河床変動の数值解析に成功している. しか しながら構造物が透過性を持つ場合に関しては, それが もたらす乱れの特性等, 不明な点が多く, 未だ確立され たモデル構築手法は示されていない.

そこで本研究では，透過性構造物への非定常3次元モ デルを用いた解析に際する基礎的研究として，道奥ら により提案された非ダルシー型の抵抗則による多孔体内 部流れの数值モデルを，3次元LESモデルによる開水路 流の数值計算に結合寸ることにより，捨石水制周辺およ び内部流れを同時に計算する手法を提案し，その有効性 の検討を行うこととする.

\section{2. 数值計算モデル}

道奥ら年による多孔体内の非ダルシー型抵抗則は時間 平均された流れに対して有效性を持つことが目的とされ ており，非定常計算での妥当性は未知である。しかしな がら本研究では，水制内部の流れにおいて平均流の值が 妥当性を持ち，十分大きいスケールでの構造を持つ場合， それに影響される開水路部分での非定常性に関しては LESモデルによっての解像が可能であると仮定し, 前述 のようなモデルの構成を提案している．流れの非定常性 に関する興味が開水路部分にある場合は，このようなモ デル化によっても現象の検討が可能であるとの仮定の下， 具体的には以下のようなモデル化を行う.

\section{（1）開水路部分でのLESモデル}

開水路部分の流れには, SmagorinskyモデルをSGS応力 モデルとしたLESモデルを用いる7゙. 空間的に粗視化さ れた基礎式は以下の連続式(1)およびNavier-Stokes方程式 (2)となる.

$$
\begin{gathered}
\frac{\partial \overline{u_{i}}}{\partial x_{i}}=0 \\
\frac{\partial \overline{u_{i}}}{\partial t}=-\frac{1}{\rho} \frac{\partial P}{\partial x_{i}}-\frac{\partial\left(\overline{u_{i}} \overline{u_{j}}\right)}{\partial x_{j}}+\frac{\partial}{\partial x_{j}}\left(2 v_{e} \overline{S_{i j}}\right)+g_{i} \\
v_{e}=v+v_{t} \\
v_{t}=\left(C_{s} \Delta\right)^{2}\left(2 \overline{S_{i j}} \overline{S_{i j}}\right)^{\frac{1}{2}} \\
\overline{S_{i j}}=\frac{1}{2}\left(\frac{\partial \overline{u_{i}}}{\partial x_{j}}+\frac{\partial \overline{u_{j}}}{\partial x_{i}}\right)
\end{gathered}
$$

ここで文字上の横線は空間的に粗視化された值，下付き 文字 $i$ は座標系の各成分を示し, $u_{i}$ : 流速, $x_{i}$ : 空間座標, $t$ : 時間, $\rho$ : 流体の密度, $g_{i}$ : 外力の加速度, $v$ : 動粘性 係数, $C_{s}$ : Smagorinky定数, $\Delta=\left(\Delta x_{1} \Delta x_{2} \Delta x_{3}\right)^{1 / 3}, \Delta x_{i}$ : 格 子スケール, $P=p+2 / 3 q, p$ : 圧力, $q$ : SGS運動エネルギー である.

実際の計算上ではこれら基礎式は細田ら ${ }^{8)}$ と同様の移 動境界適合座標上に座標変換され, 式(3)の運動学的条件 により計算された水位に応じて水面での境界が時間的に 変動する.

$$
\frac{\partial H}{\partial t}+u \frac{\partial H}{\partial x}+v \frac{\partial H}{\partial y}=w
$$

ここで, $H$ : 水位, $u, v$ : 流速の水平方向成分, $w$ : 流 速の鈆直方向成分, $x, y$ : 座標系の鉛直方向軸である.

\section{（2）非ダルシ一型抵抗則を用いた多孔体内のモデル}

Ward $^{9)}$ の示した非ダルシー型抵抗則を用いて道奥ら ${ }^{4)}$ により提案されたRANS型水深平均2次元モデルを，3次 元に拡張することにより，多孔体内の流れの基礎式(4)を 得る.

$$
\begin{aligned}
\frac{1}{n} \frac{\partial U_{s i}}{\partial t}= & -\frac{1}{\rho} \frac{\partial p}{\partial x_{i}}-\frac{1}{n^{2}} U_{s i} \frac{\partial U_{s j}}{\partial x_{j}} \\
& +\frac{1}{n^{2}} \frac{\partial}{\partial x_{j}}\left(-\overline{u_{s i}^{\prime} u_{s j}^{\prime}}\right) \\
& -\left(\frac{v}{K}+\frac{c}{\sqrt{K}} \sqrt{U_{s j} U_{s j}}\right) U_{s i}
\end{aligned}
$$

ここで下付き文字のsは見かけの流速を表し, 間隙率nを 用いて， $u_{s i}=n u_{i}$ と表せる. 大文字Uは流速のアンサンブ ル平均を示し, $u_{i}=U_{i}+u_{i}{ }^{\prime}$ と表せ, LESにおける空間フィ ルタリングと明示的に区別するためにこのような表現を 用いた. ただし $u_{i}^{\prime} は U_{i}$ からの変動成分であり, さらに式 (4)中の右辺第3項における括弧内はレイノルズ応力を示 す. 右辺第4項は多孔体内の流水抵抗力を示し, 特に括 弧内第1項はDarcy則に相当する層流抵抗力, 第2項は乱 流抵抗力である. 道奥ら ${ }^{4}$ によると多孔体内では右辺第4 項による抵抗が卓越することから, 計算中ではレイノル ズ応力の影響を無視している. ここで，Kおよびcは多孔 体の特性パラメータであり, 以下のように与えられる.

$$
\sqrt{K}=e d_{m}, \quad c=f\left(\frac{d_{m}}{\sqrt{K / n}}\right)^{-3 / 2}
$$

ここで, $d_{m}$ : 平均粒径, $e, f$ : 無次元の形状係数である. なお多孔体内での連続式に関しては，見かけの流速に 対して式(1)を適用する.

\section{（3）計算手順}

開水路部では，移流項計算にCIP法 ${ }^{10)}$ 用いることか ら, 分離解法を用いて, 圧力項, 粘性項, 移流項と段階 的な計算を行っている. 圧力項に関してはSMAC法を用 
いることで連続式との連立を行い，さらに式(3)により得 られた水位を代入して繰り返し計算を行うことで，水位， 圧力の次ステップの収束值を求める．粘性項の計算に関 しては，透過型水制以外の固体壁に対して壁法則を用い る.

多孔体内部の流れに対しても移流項にCIP法を用いる ことから，同様に分離解法を適用している. ただし水位 計算に際して運動学的条件の適用性が不明であるため, 透過性構造物内部では式(3)を用いずに，流速フラックス の水深方向積分值から連続性を満たすよう水位を求めて いる. またその際に多孔体内部での水位の時間的変動が 開水路ほど激しくないと考えられることから, 圧力項と の繰り返し計算による連立を行わず，各計算ステップの 最後に4段のRunge-Kutta法を利用して求めている.

変数はスタッガード格子状に配置され，流速の各成分 はセル境界に位置する. 開水路部と透過水制の境界はセ ル境界上にあるが，流速フラックスが等しいという条件 を境界条件として与え, 圧力項と連続式との連立による Poisson方程式を解いている. また通常の固体壁では壁法 則を用いてせん断力の影響を考慮するが, 透水性構造物 壁面では道奥ら゙倣い，境界に並行する水制内部での 見かけ流速と開水路部での実流速を，境界で法線方向に 微分したものを粘性項での2階微分に取り込むことで， その考慮を行う。

\section{3. 計算条件}

本研究では, 道奥ら年による非越流型透過水制の水 理実験（case3）の值を参考に計算条件を定める. 計算 領域の形状を図-1に示寸。水路長: 15.0(m), 水路幅: 2.0(m), 水制長: $1.0(\mathrm{~m})$, 水制幅: 0.3(m), 上流端加ら水制 上流側面までの距離: $4.0(\mathrm{~m})$ としている. 計算での水理条 件は, 流量: $0.0519\left(\mathrm{~m}^{3} / \mathrm{s}\right)$, 水路勾配: $1 / 800$, 上流端水深: 0.096(m), 下流端水深: $0.037(\mathrm{~m})$, 上流端代表流速 $U_{0}$ : 0.283(m/s) とし, また捨石を構成する礫の条件を, 粒径 $d_{m}: 0.035(\mathrm{~m})$, 間隙率n: 0.38としている.

計算に用いる各係数としては, Smagorinsky定数: $C_{s}=0.1$, 透過水制材料の形状係数: $e=0.015, f=30.0$ とする.

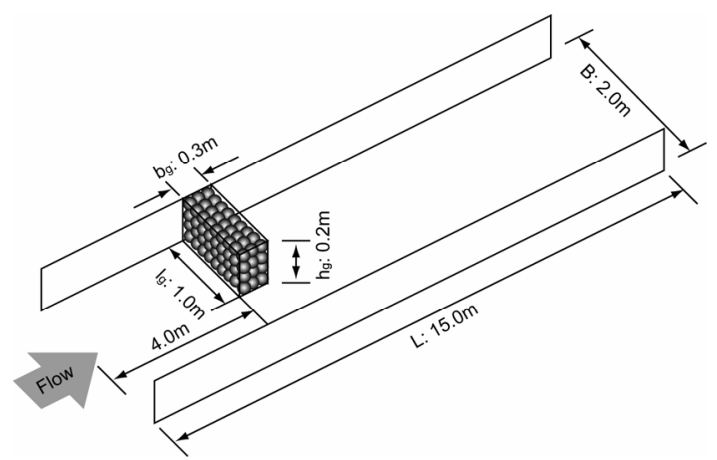

図-1＼cjkstart計算領域の形状
また計算時の格子数を，流下 $\times$ 横断 $\times$ 鈆直方向にそれぞ れ，300×20×20とし，計算時間きざみを0.001(s)，計算 ステップの総数を 300000 ステップとしている. さらに流 入端では流速分布と水位を, 流出端では水位のみを条件 として与え, 自由流出条件としている.

\section{4. 計算結果と既存の研究との比較}

まず，時間平均された結果について既存の実験值との 比較を行い，定常状態でのモデルの妥当性を検証する. 図-2は, 水位の比較, 図-3では水深平均流速の比較, さ らに図-4は水制下流端から $\mathrm{x} / h_{0} \doteqdot 4.0$ での基準化された流 下方向流速の横断方向分布の比較を示寸.

これらの水深平均された結果において，モデルの良好 な再現性が確認できる.しかしながら図-4においては,
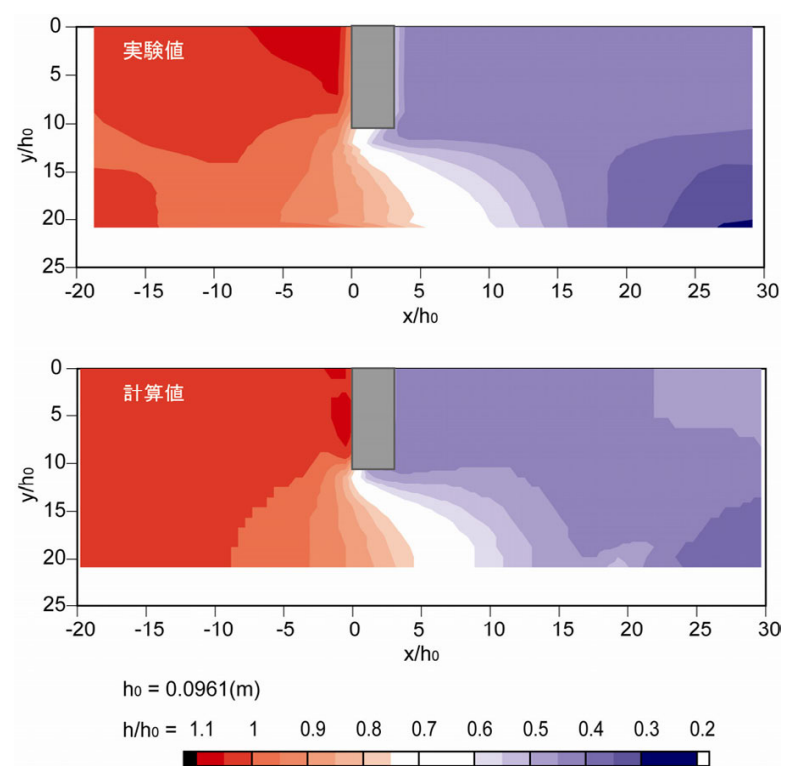

図-2＼cjkstart基準化された水位の比較（上が実験值，下が計算値）
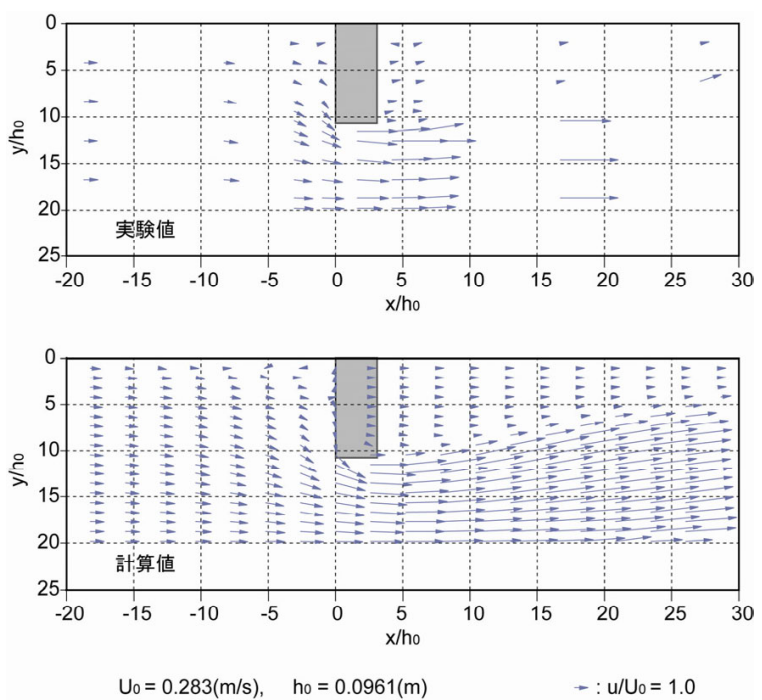

図-3＼cjkstart水深平均流速の比較（上が実験值，下が計算値） 
モデルによる計算結果が実験值のピークを十分捉えられ ておらず，流速分布を平均化する方向に現れていること が確認できる.

\section{5. 計算結果の詳細な検討とモデルの問題点}

前章での比較から平均化された流れの特性に関して本 モデルが良好な再現性を有していることが確認できた。 この結果より，本モデルが妥当性を有していると考え， 流れの3次元性および非定常性に関しての考察を進める. 流れの3次元性に関しては, 渦のもたらす組織構造の 把握が重要となる。一般的には, 渦度の等值面を描画す ることでその定性的な把握を行うが，渦度の算定にあ たって，その基準となる軸が固定されてしまうために3 次元的な構造を把握寸ることが困難となる点や，平均流 によるせん断が卓越する場合に内部での瞬間的な渦の構 造を発見寸るのが困難である点など，本研究への適用性 には限界がある。そのため, ここでは $\lambda_{2}$ 法による瞬間的 な等值面を描画することで，流域内部の渦の組織的構造 を探ることとする． $\lambda_{2}$ 法はJeongら ${ }^{111} に よ り$ 提案された手 法であり，渦による回転運動の中心では圧力は流体の遠 心力とつりあう必要が無いために極小をとるという特性 を利用する方法の一つで, $S^{2}+\Omega^{2}$ テンソルの固有值のう ち2番目に大きい值が負となる地点を渦の中心部である と考える. $\lambda_{2}$ 法により示されたチューブ状の形状を持つ 等値面によって, 回転運動の軸が模式的に示されると考 えられる. 図-5は瞬間的な $\lambda_{2}=-0.05$ 等值面および流速 の横断方向成分を示寸．ここでは，第一に水制直前から チャンネル急縮部に掛けて生じる流体のもぐりこみによ り生じる渦（渦A），第二に水制右岸下流側にせん断に よって生じる鉛直の渦（渦B），第三に右岸下流域に生 じる壁面からの剥離に伴う渦（渦C）およびそこから連 なる水平方向の渦が確認できる.

また横断方向流速成分から確認できる点として, 水制 の直下流の域において, 横断方向の流速成分がほとんど 確認できない点が挙げられる．もぐりこみから水制側面 の底面近傍を右岸側に進み2次流の生成につながるはず の流速に関しても，その収束は比較的早く（領域a）, 流れの中で流下方向を軸とした回転はそれほど強く見ら れない.

これに関連して，計算結果内では定常時に確認できる 間欠的な剥離渦は第三のタイプの下流側のみであり，大 きなせん断面を持つと予想される水制先端から下流にか けての地点では第二の渦（渦B）から放出されれる水平 の剥離渦が生じていない．この構造は定常に達してから ほぼそのままの形を保って推移し，大きな構造の乱れを ほとんど生成しない.

この計算結果における透過水制周りの流れの特徵は, 同様の水理条件で行われた不透過型水制に対しての数值
計算結果と比較するとより明らかになる. 図-6は不透過 水制周辺の瞬間的な $\lambda_{2}=-0.05$ の等值面および流速の横断 方向成分を示す. 不透過水制の場合には $\lambda_{2}$ 法により示さ れる渦の構造は透過水制の場合と比較してはるかに複雑 であり, 渦B周辺からの間久的な剥離渦の放出が確認で きる．また透過水制の結果と大きく異なり，領域aでの 反時計回り（上流から見て）となる2次流が，不透過型 水制の場合は, 明瞭に存在し, より下流まで到達する.

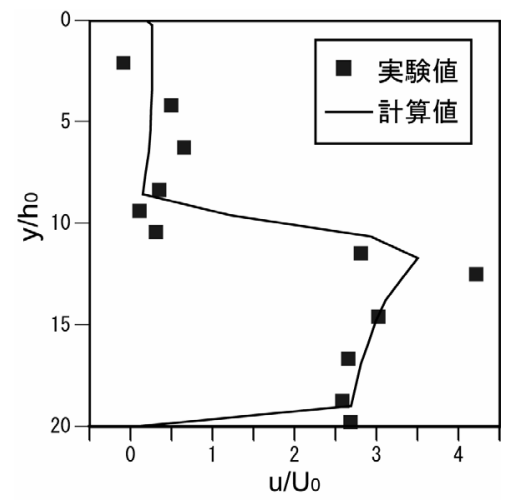

図-4 $x / h_{0} \doteqdot 4.0$ での水深平均流速の横断方向分布

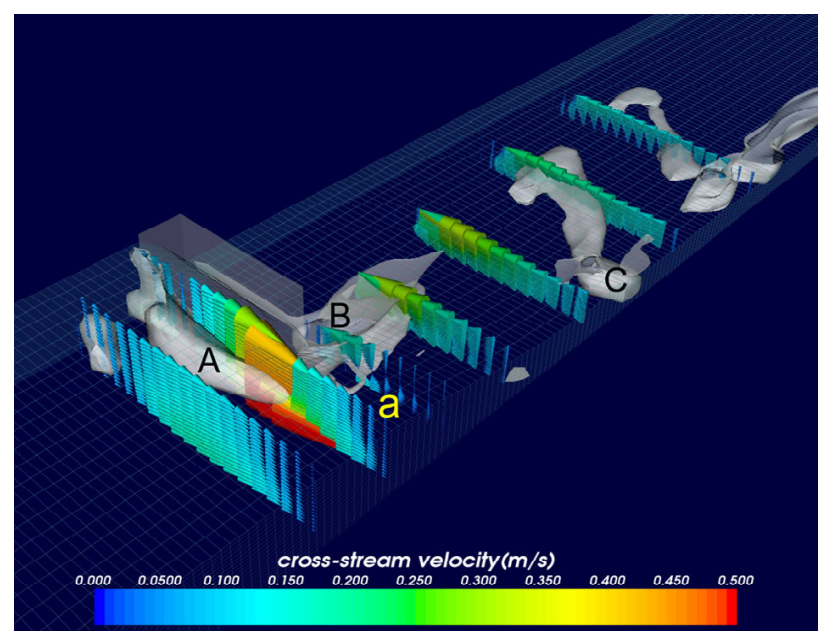

図-5 $\lambda_{2}=-0.05$ での等値面と横断方向流速成分（透過水制）

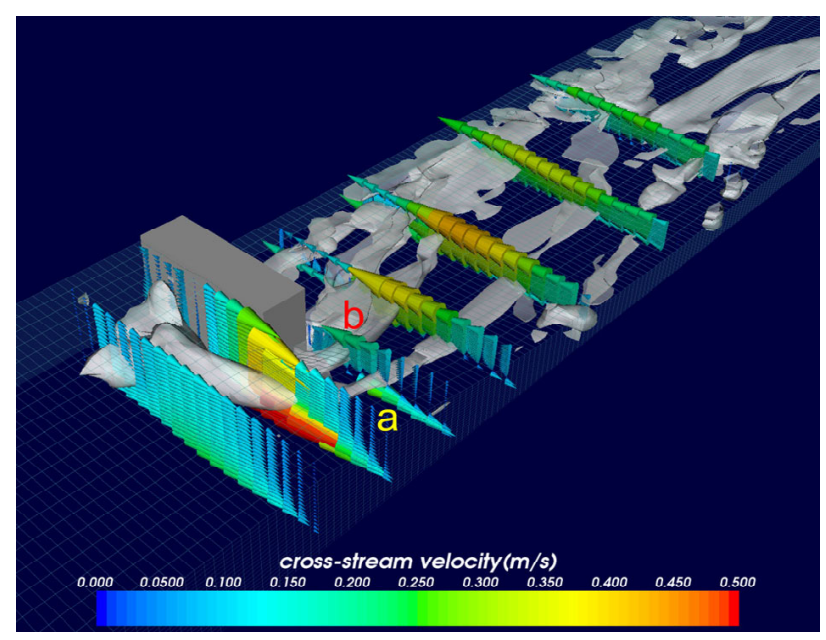

図-6 $\lambda_{2}=-0.05$ での等値面と横断方向流速成分（不透過） 
さらに水制下流で領域aの2次流に対し，逆方向に領域b で時計回りに生じる2次流も，透過型水制の場合よりも 明瞭に現れる. 水制先端から下流にかけて，2次流が明 瞭にあらわれる不透過水制周辺の流れにおいては剥離渦 の放出が確認でき，2次流の弱い透過水制周辺では確認 が難しいという結果から，水路幅スケールでの平均流か ら受ける渦構造への影響が，捨石等を用いた透過水制と， コンクリート等を用いた不透過型の水制とでは異なると いらことが考えられる. 寸なわち，水制下流での水質浄 化や，形状的な特性から得られる景観上や生態系に対寸 る透過水制の利点以外にも，水制上流端でのもぐりこみ による圧力勾配を緩和し，狭窄部での2次流と水制背後 の死水域での逆方向2次流を抑制し，それによって生じ る剥離渦等の大規模な流れの不安定性を抑制する効果を, 透過水制により期待できる.

しかしながら，上記の結果はあくまで平均流の大規模 な構造から推測できる差異に基づいており, 透過水制周 辺ですべてのタイプの乱れが抑制されるということを証 明するものではない. 実験時 ${ }^{12)}$ の状況（文献中のPhoto 6-7）では，水制下流域にはっきりとした水面波紋が確 認でき，モデルで再現されなかった別の種類の乱れが存 在することを示している.

このような乱れの発生源としては, 多孔体内部や周辺 部で生成される小規模の乱れの影響が考えられる. 本研 究では多孔体内部のモデル化において，乱流による抵抗 は時間平均された流れからの考察に基づいて与えられて おり，水制内部の瞬間的な乱れを再現できないことは予 想されたが，問題は，このような小規模乱れが，LES モデルで再現される流れの非定常性にも大きく影響する 点にある.

小規模乱れを考慮するために，透過水制近傍で等方乱 れが発生していると仮定し，正規乱数に基づく乱流生成 によってモデル化を試みた．正規乱れは透過水制の下流 側と先端側面のそれぞれの第一近傍点における法線方向 の流速成分に対して与え, 正規乱数の分散の值は, 浅水 流での格子乱流をモデル化したUijttewaalら ${ }^{13)}$ の実験によ り示された，対数グラフ上において-1.3の傾きを持つ乱 流強度の減衰則に基づいて式(6)により与えた.

$$
\ln \left(\frac{\overline{u^{\prime 2}}}{{U C^{2}}^{2}}\right)=-1.3 \ln \left(\frac{x}{D}\right)+b
$$

ここで， $U_{c}$ : 多孔体内の実流速， $x$ : 多孔体壁面からの 距離, $D$ : 多孔体を構成する粒子の直径, $b$ : グラフ切片

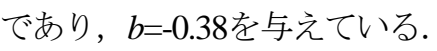

この人工的な乱れの効果を検討するため，式(6)による 乱れを付加した計算の透過水制周辺の乱流強度を図示し， 乱れを付加しない場合と比較を行う．図-7は流速の流下 方向成分に関して乱れ強度の等值面を表したもので, 図-7aが透過水制に正規乱れを付加しない場合，図-7bが 正規乱れを付加した場合である.これらの比較では，乱 れの人工的付加が, 乱れ分布のパターンを保ちつつ，そ
の強度のみを上げていることが分かる．しかしながら， この付加的乱れも，必要とされる乱れの生成について十 分でないことが，図-8の不透過水制の場合の乱れ強度と の比較から明らかである（図-8では図-7と比較して描画 される乱れの域を100倍に広げている）。

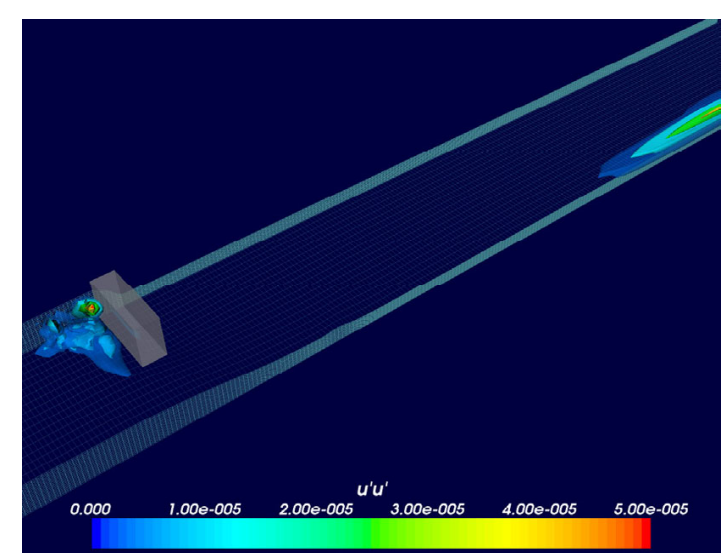

図-7a＼cjkstart流下方向乱流強度の等値面

透過水制，捨石水制近傍点での式(6)による乱れ付加なし. $0.0\left(\mathrm{~m}^{2} / \mathrm{s}^{2}\right) \leqq u^{\prime} u^{\prime} \leqq 5.0^{*} 10^{-5}\left(\mathrm{~m}^{2} / \mathrm{s}^{2}\right)$ にこいて描画.

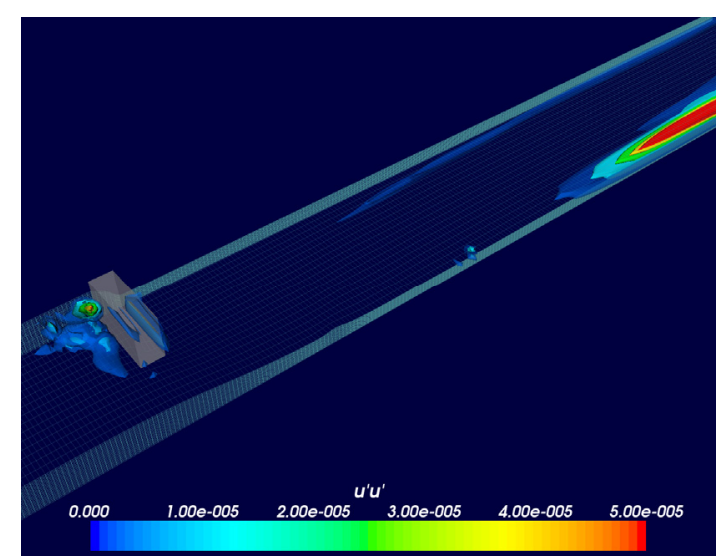

図-7b 流下方向乱流強度の等值面

透過水制，捨石水制近傍点での式(6)による乱れ付加あり， $0.0\left(\mathrm{~m}^{2} / \mathrm{s}^{2}\right) \leqq u^{\prime} u^{\prime} \leqq 5.0^{*} 10^{-5}\left(\mathrm{~m}^{2} / \mathrm{s}^{2}\right)$ にこついて描画.

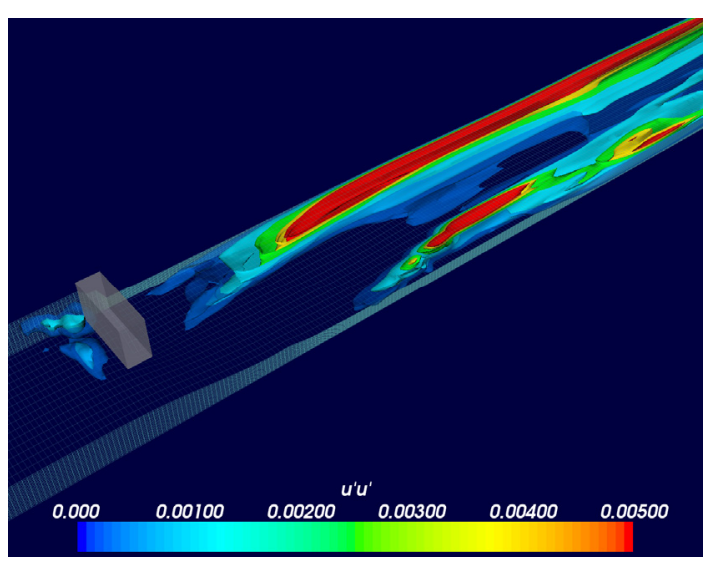

図-8 流下方向乱流強度の等值面

不透過水制，水制近傍点での式(6)による乱れ付加なし． $0.0\left(\mathrm{~m}^{2} / \mathrm{s}^{2}\right) \leqq u^{\prime} u^{\prime} \leqq 0.005\left(\mathrm{~m}^{2} / \mathrm{s}^{2}\right)$ について描画. 
ここで、不透過水制においては表面が十分に平坦であ ると仮定し，式(6)による水制近傍での人工的乱れは付加 しておらず，不透過水制下流に現れる乱れは平均流の影 響から出現していると考えられる．正規乱れの付加に よっても，透過水制の乱れの強度はまったく不透過水制 の乱れの強度に届いていない. 対象とした実験の未発表 資料によれば，透過水制の場合も不透過と同オーダーの 乱れが生じていることから，式(6)による単純なモデル化 では，多孔体の形状的特質に由来寸る透過水制付近の乱 れが計算では十分に全体へと反映されず，現在のモデル では小スケールの乱れから大スケールの乱流への渦の合 成 ${ }^{13)}$ こついてのモデル化が，十分でないことが原因と考 えられる．同様の乱れの合成が捨石水制下流でも生じて いると仮定すると，乱れの合成を誘発し得る特定の構造 を持った小さな乱れを捨石水制近傍で与えなければなら ず，式(6)を仮定した際の等方的な乱れという前提が成り 立たない可能性がある. 実際に, 本計算では流下方向の 格子サイズ $(0.05 \mathrm{~m})$ と捨石水制の粒子の平均粒径 $(0.035 \mathrm{~m})$ とが，ほぼ同様の大きさであり，本来なら捨石の後背流 の組織的構造が格子スケールで解像されるべきであった.

しかしながら，このような捨石背後の組織的な乱れを 再現寸る上で，多孔体内において平均流れ特性に基づく モデル化には限界がある. 木村ら ${ }^{14)} の$ 角柱周辺の流れの モデル化のように，捨石の形状自体を格子によって解像 できることが望ましいが，計算格子の作成や境界条件の 複雑さを考慮すると， 3次元的に積み上げられた捨石に 対し同様の手法を適用するのは不可能である。また単純 にLESの計算格子を高精度化したところで，格子サイズ に対する相対的な捨石粒子径の影響はかえって大きくな り, 問題の解決にはつながらない。このようなことから, 非ダルシー型抵抗則による多孔体流れと, 開水路流の LESを組み合わせた捨石構造物周辺の流れのモデル化に 際しては，乱れや流れの非定常性の再現を目的とする場 合，捨石スケールの組織構造を持つ乱れをLESによ゙う組 み込むかが，今後の課題である.

\section{7. 結論}

本研究では，非ダルシー型抵抗則を用いた多孔体内の 流れのモデルをLESによる開水路流れの計算に結合する ことで，捨石による透過水制周辺と内部の流れの3次元 的な把握を試み，さらにモデルの特性について検討を 行った. 本研究で得られた知見を要約する.

1) 実験結果との比較により, 時間平均および水深平均 された流れに関して，本モデルが妥当な再現性を有して いることを確認した.

2) 透過水制は不透過水制よりも，水制前面でのもぐり
こみによる圧力勾配を緩和し，開水路部における2次流 の発生を抑制する.さらに2次流が誘発する水路幅ス ケールの流れの非定常性も抑制する.

3) 本モデルは水制背後からの捨石粒子スケールの乱れ と水制下流での乱れの合成を合理的に記述できない，乱 れの瞬間的構造を再現するために，これらを解決するこ とが今後の課題である.

\section{参考文献}

1) 前野詩朗, 道奥康治, 大西利典, 森永 智 : 捨石堰の破壊時 の水理特性, 応用力学論文集, Vol.5, pp.657-664, 2002.

2) 前野詩朗, 道奥康冶, 森永 智, 菊池慶太 : 捨石堰周辺の流 況解析，水工学論文集，第48巻, pp.829-834, 2004.

3) 道奥康治, 前野詩朗, 羽根田正則, 古澤孝明 : 捨石堰を越流 寸る流れの構造と流量解析，土木学会論文集，No.740/II-64, pp.131-142, 2003.

4) 道奥康治, 南條雅志, 石垣泰輔, 前野詩朗 : 捨石水制が冠水 した開水路流の二次元二層流モデル, 土木学会論文集, No.782/II-70, pp.31-50, 2005.

5) Akahori, R.: Modeling sediment transport in eddy recirculation zones of the Colorado River in Grand Canyon, $\mathrm{PhD}$ dissertation, Arizona State University, 2007.

6) 長田信寿, 細田 尚, 村本嘉雄, 中藤達昭 : 3次元移動座標 系・非平衡流砂モデルによる水制周辺の河床変動解析，土木 学会論文集, No.684/II-56, pp.21-34, 2001.

7) Deardorff, J. W.: A numerical study of three-dimensional turbulent channel flow at large Reynolds numbers, Journal of Fluid Mechanics, 41(2), pp.453-480, 1970.

8) 細田 尚, 長田信寿, 村本嘉雄 : 移動一般座標系による開水 路非定常流の数值解析, 土木学会論文集, No.533/II-34, pp.267-272, 1996.

9) Ward, J. C.: Turbulent flows in porous media, Journal of Hydraulic Engineeering, ASCE, Vol.90, HY5, pp.1-12, 1964.

10) Yabe, T. and Aoki, T.: A universal solver for hyperbolic equations by cubicpolynomial interpolation I. One-dimensional solver, Comp. Phys. Comm. 66, pp. 219-232, 1991.

11) Jeong, Jinhee., and Hussain, Fazle, On the identification of a vortex. J. Fluid. Mech., 285, pp.69-94, 1995.

12) 道奥康治, 石垣泰輔, 前野詩朗, 竹原幸生, 江藤剛冶, 南 條雅志, 羽根田正則 : 捨石で構成された堰・水制の水理機能, 京都大学防災研究所年報, 第47号B別冊, 2004.

13) Uijttewaal, W. S. J. and Jirka, G. H.: Grid turbulence in shallow flows, J. Fluid Mech., Vol.489, pp.325-344, 2003.

14) 木村一郎, Uijttewaal, W. S. J., 細田 尚 : 二次元および三 次元RANSモデルによる浅水格子乱流の数值解析, 水工学論 文集，第51巻,pp.799-804, 2007.

(2007. 9. 30受付) 